\title{
PATHWAYS FOR TEACHING STATISTICS IN THE HEALTH AREA
}

\author{
$\underline{\text { Rodrigo Fioravanti Pereira }}{ }^{1}$ and Ileana María Greca ${ }^{2}$ \\ ${ }^{1}$ Centro Universitário Franciscano, Brazil \\ ${ }^{2}$ Universidad de Burgos, Spain \\ prof.rodrigopereira@gmail.com
}

The teaching of statistics has been gaining prominence and affirming itself as an area of study, especially due to the need to qualify the training of professionals. In this paper, we aim to discuss the history of statistics teaching based on two existing reviews of literature written in 1995 and 2007, respectively. Therefore, we conducted our own review, focusing on higher education in the health area. In regards to the studies that have been published since 2007, it is evident an increase in the use of the Internet, the search for methods for teaching specific contents and the effort to promote literacy as well as the distribution of statistical results. We believe that the usage of methodologies based on learning theories and developed through research studies on real data supported by virtual and face-to-face technologies is appropriate with the evolution that the teaching of statistics demands. This link may improve the training of health professionals.

\section{INTRODUCTION}

This article approaches some issues concerning the teaching of Statistics that have been raised from the end of the 1970s until today. The focus, though, is in the literature reviews made by Garfield (1995) and Garfield and Ben Zvi (2007) in comparison with our own review on it for the health area from 2007 to 2017 . The aim of this review is to identify the strong and weak aspects of this teaching field and to propose some contributions for such. This focus is currently important because according to Ing $(2016$, p. 1), "statistics literacy is a needed skill for physicians to understand and implement research. Although a biostatistician can be sought for, it is mandatory for the clinician who does the research to comprehend the principles of the statistical analysis."

In 1995, Joan Garfield published a literature review under the premise that educators need to know what they really expect their college students to learn, in order to design classes and use evaluation to determine if they are being effective and if the students are developing statistical comprehension and competence. Her article has had 610 citations by March 18, 2018, according to Google Scholar. Garfield's review lists 40 studies published between 1977 and 1993, from which 22 were published in the United States, 6 in the Netherlands, 4 in the United Kingdom and 8 of them do not inform the country of publication. 30 out of 40 articles are from the statistics teaching field, and from those, 18 are about the teaching of probability. The other 10 articles concern the teaching of Mathematics (2), the learning process in general (6), evaluation (1), and the teaching of Physics (1). In short, the author considers that, despite the great amount of research, most studies only brought general implications and, therefore, a lot was necessary to be learnt about specific problems:

- How can the usage of computers improve the learning of particular concepts and help overcoming wrong conceptions in calculating the mean value or variability of samples, for example?

- Which techniques are more effective to confront and overcome wrong particular conceptions?

- Which specific activities work better in small groups to help understanding particular concepts and developing specific reasoning skills?

- What kind of procedures and evaluative materials can better inform teachers about the students' understanding?

Garfield and Ben-Zvi (2007) conducted a review of literature in order to determine the pathway taken by the teaching of Statistics until 2007. They highlight the growth of conferences and publications devoted to the research in statistical education even considering this area as new, emergent, difficult to find its basis, and evolve from its basis because its studies are diluted in publications from other several subjects.

In 2002, the Statistics Education Research Journal arose as the first periodical dedicated to high quality publications about research on the teaching of Statistics. There were also International Conferences on Teaching Statistics, the International Group for the Psychology of Mathematics 
Education, the Mathematics Education Research Group of Australasia, the International Congress on Mathematics Education meetings and the International Statistical Institute, which also report research in the area of statistical education.

Garfield and Ben-Zvi (2007) highlight that the research examined particular activities or interventions and some technological tools and teaching methodologies. Most of these studies involved the classes of the own researchers, sometimes examining one class, sometimes looking at many classes in the same institution. However, the difficulty for establishing which method was better for the teaching of Statistics was notorious. They also point that "developing a deep understanding of statistical concepts is quite challenging and should not be underestimated" (p. 379). This process is slow; it needs to be well planned about the pathway to be taken, the tools to be used, the choice of issues to be discussed and the way of promoting the review of those ideas. The also highlight that the studies should focus on the development of some specific topics of Statistics to help teachers understand mistakes and difficulties of comprehension that are common for those topics. This review also pointed that the quantitative studies lacked consistent and high quality evaluation instruments to check the students' learning results, for in most cases only the grades of the disciplines they took were used. These measures did not bring evidence of validity and trustworthiness and usually did not measure general results.

Finally, the authors stated what they called the eight principles for the learning of Statistics: i) knowledge construction, ii) active engagement in learning activities, iii) practice, iv) not underestimating the difficulty students have in understanding basic concepts, v) not overestimating how well students understand basic concepts, vi) students confronting errors in reasoning, vii) technological tool use for visualization and exploration, not only for following algorithms with predetermined endings, and viii) consistent helpful feedback (pp. 387-389).

The work from Tishkovskaya and Lancaster (2012) differentiates itself from the previous ones when it focuses on the research that uses several tools based on the web for the teaching of Statistics. The authors indicate that, despite the amount of options and wide use of the Internet, an adequate methodology is necessary for its efficient use as a teaching tool, even if teaching proposals are centered in the student (student-centered learning) or directed by him (self-directed learning). However, teachers' intervention is required for effective learning. The proposals that link the present with online resources had a positive performance.

On concerning teaching and learning of Statistics, this review found the following main problems:

- Focus on mathematical and mechanical aspects of knowledge;

- Mathematics phobia, anxiety, negative attitude and predisposition against Statistics;

- Ideas about Probability and Statistics that are of difficult comprehension for students of other areas;

- Deficit in basic statistical knowledge and lack of mathematical background;

- Statistics courses taught without any link to the specific area of study or by an expert who is not a statistician;

- Lack of a valid and reliable instrument for the evaluation of statistics knowledge;

- Lack of graduation programs and courses to qualify statistics teachers.

\section{CRITERIA FOR OUR OWN LITERATURE REVIEW}

Our review aims to proofread papers on the teaching of Statistics at the university, and, specifically, in the health area. It contains only complete articles published online, in journals or events that have peer review, contemplating only works published between 2007 and 2017. Articles published in English, Spanish and Portuguese were selected.

The online searching tools within article repositories were used to find material from the areas of Health (PubMed), Statistics (ISI), Teaching of Statistics (IASE) and Teaching of Mathematics (RELIME). Other scientific search engines were used (Web of Science, Dialnet, Scielo, Periódicos Capes, Google Scholar, Mendeley) as well as Google. Some automatic tools for warning by email were used which monitor the most recent publications considering the pre-determined key words from Google Scholar, Mendeley, PubMed and ScienceDirect. For each searching tool, we entered the expressions "Teaching Statistics" or "Teaching Statistics AND University Level," after 
that, the research went under a refinement according to the filters available to narrow the results, like "Health Care", "Science Technology" or "Educational Research". It is important to highlight that the tools can find these terms in other languages and that we only used the results in English, Spanish and Portuguese.

The articles were pre-selected among the ones filtered by the tools. Article titles were analyzed in order to identify the works on the teaching of Statistics for the Health area at college. When such indication did not appear, we started analyzing the abstracts. At the end, the sample analyzed had 38 articles.

\section{CATEGORIES OF PAPERS IN THE LITERATURE REVIEW}

\section{Psychological Aspects}

As it seems, the proper difficulties of the statistical content do not constitute the only challenge to be faced by Teachers of Statistics, there is an external agent that makes it harder and impacts the pedagogical performance of teachers: the negative view of students upon Statistics, in particular, in the health area. Stress, demotivation and even repulse is noticed on students especially when they cannot link it with the health area or because classes are not motivating, as reported by Oliver, Galiana, Cebrià and Sancho (2014) and Espindola, López, Miranda, Ruiz, and Díaz (2014). The statistical anxiety constitutes an emotion characterized by extended worry, intrusive thoughts, mental disorder, tension and physiological activation when students are exposed to contents, problems, classroom situations or evaluative contents that involve Statistics (Zeidner, 1990).

Six articles were chosen concerning statistical anxiety, which together involved a sample of 1936 students from Brazil (2 papers), Spain, Canada, Cuba and Argentina. Espindola et al. (2014) found a decrease in statistical anxiety when using a participative methodology. Hernandez, Santos, Silva, Mendes, and Ramos (2015) and Turik, Viali and Moraes (2012) concluded that statistical studies that are contextualized to the student's reality can contribute to diminish this kind of anxiety. León and Vaiman (2013) verified that the exposure to Statistics at school improves the performance at university, but not necessarily the feeling that they have about the subject. Vigil-Colet, LorenzoSeva and Condon (2008) determined that the specific results on the statistical anxiety scale have a meaningful relation with academic performance in Statistics, while wider measures of anxiety do not.

\section{Teaching Methodologies}

Inadequate teaching methodologies of Statistics may impact the formation of a future professional from the health area, once Evidence Based Medicine is a reality and students may face these situations negatively because of the Statistics and Mathematics that it demands. Because of that, in the United States, the Guidelines for Assessment and Instruction in Statistics Education (GAISE) College Report (GAISE College Report ASA Revision Committee, 2016) was created, which recommends the following.

1. Teach statistical thinking. Teach statistics as an investigative process of problem-solving and decision-making. Give students experience with multivariable thinking.

2. Focus on conceptual understanding.

3. Integrate real data with a context and purpose.

4. Foster active learning.

5. Use technology to explore concepts and analyze data.

6. Use assessments to improve and evaluate student learning (p. 3).

Involving students in all steps of the research makes them more interested in the analysis steps, which is in accordance to the recommendation of GAISE: to propose activities which may include the designing, understanding and collection of data so that students can notice the whole process of the work (Nowacki, 2015, p. 3). The research involved 32 Medicine students divided into groups of four, who developed their own issue of research based on some previous readings given by the teachers.

In this sense, the work of Lima (2010) shows the result of the integration of Epidemiology with Statistics, developed between 2002 and 2008 involving 240 students of the Medicine Course of 
a Brazilian university. The students were encouraged to build their own research issues from the health necessities of the region. As an extra class result, the researcher highlights the determination of the epidemiological profile of some endemic diseases in the region.

Concerning the use of technology, the wide usage of computers in Statistics classes is noticeable, once computing is one of the responsible for the popularization of this subject in the health area, with specialized software programs as the "Epi info", created by CDC (Center for Disease Control and Prevention) to work with epidemiological data. However, despite the computing accessibility, Tishkovskaya and Lancaster (2012) point that there is a lack of studies which include technology in a pedagogical way in classes and not only as a simple substitution of the statistical algebra. However, the Web has been a fertile land innovative pedagogical experiments. A prove of that is the dissemination of the MOOC's (Massive Open Online Courses) available by some renowned teaching institutions as MIT (Massachusetts Institute of Technology), but yet, they are focused on recorded classes, according to Tavares (2014). Also, none of the articles from the sample evaluates any full distance learning of statistics.

\section{Research Materials}

Traditional ways of accessing the students statistical reasoning, with grades or even exercises, may not correspond to what they really know; pair or small group discussions can be more revealing about the students' knowledge (Zieffler et al., 2008). In this sense, there are few quantitative instruments for the evaluation of the statistical reasoning, and most of them focus on the study of probability and a few are concerned with the reasoning of statistical contents. This way, it is necessary to have more multiple-choice instruments validated which may allow the access knowledge about the reasoning of statistical concepts such as distribution or variability. Also, the usage of qualitative methods can offer some means for developing quantitative instruments. The Statistical Reasoning Assessment is one of the first objective instruments developed to analyze the statistical reasoning of students, published by Garfield in 1998, as described by Tempelaar, Gijselaers and Loeff (2006). Another instrument also used was the SAS Scale - Statistical Anxiety Scale; Oliver et al. (2014) identified the validity evidence of the SAS scale.

\section{FINAL CONSIDERATIONS}

The negative attitude on Statistics can be faced with tools that have already helped mathematics with the adoption of methodologies that are based in learning theories aiming to have this positive transformation minimally achieved, without depending on pedagogical experiments based on intuition and the experience of each teacher.

The investigative methodologies, such as the ones showed in Nowacki (2015) and Lima (2010), usually have good results, even though they are limited to reduced spaces and time. If well controlled and developed through a qualitative research, these experiences may generate other researches, of objective character and with generalization intentions.

When observing the performance of a doctor during anamnesis, for example, it is noticed that the investigation is inert to its professional doing. So, when adopting statistics teaching methodologies that are still focused on the traditional ways, it conveys the idea that it is totally apart from the physician's work, contributing towards statistical anxiety and the detachment of the future physician from this important tool.

Torres and Rossi (2013) emphasize that if the health professional considers Statistics only a tool, she or he will be at the risk of diminishing its importance and simplifying its use, which may bring some application mistakes. However, considering that statistical knowledge is in the essence of quantitative research, simplifying its use or diminishing its importance can impact the scientific view of the professional. From this point of view, the qualification of health professionals can vary according to their statistical knowledge, supporting the idea of Markert (2013). Markert affirms that if the inappropriate use of Statistics is avoided in scientific dissemination, the teaching and learning process of the subject for the health students will be improved and consequently, the health care of patents will do better.

Thus, the usage of methodologies based on learning theories, developed in environments that value the investigation about real data and that are sustained by computing resources developed in 
hybrid environment (present and virtual) are in accordance to the evolution that the statistics teaching demands in order to improve the learning of students from the health area.

However, the development of the research activity requires a Constructivist approach, since knowledge is not transmitted or passed on, but constructed through the interaction between the individual and the physical, social environment in an adequate context (Becker \& Leão, 1999). The learning context needs to have a harmonious interaction between teacher and student in order to consider the important affective aspects involved in a didactic interaction for reducing statistics anxiety that impairs the learning of quantitative methods by health students.

However, the Constructivist approach is not a technique, but a stance for teaching and learning. So it is advisable for the teacher to adopt a methodology that has theoretical support, such as the problem-solving one, to ensure the establishment of the Constructivist environment. In addition, it is necessary to improve the understanding of how students construct mathematical knowledge through learning theories, such as Vergnaud's theory of conceptual fields, for example.

\section{REFERENCES}

Espindola Artola, A., López Benítez, R., Miranda Carbonell, M., Ruiz Socarrás, J. M., \& Díaz Garcia, G. M. (2014). Estrategia didáctica para disminuir el estrés académico hacia el contenido estadístico en los estudiantes de medicina. Humanidades Médicas, 14(2), 499-521. Retrieved from http://scielo.sld.cu/scielo.php?script=sci_arttext\&pid=S1727$81202014000200016 \& \operatorname{lng}=\mathrm{es} \& n r m=$ iso\&tlng=es

GAISE College Report ASA Revision Committee (2016), Guidelines for Assessment and Instruction in Statistics Education College Report 2016, Alexandria, VA: American Statistical Association.

Garfield, J. (1995). How students learn statistics. International Statistical Review, 63(1), 25-34. http://doi.org/10.2307/1403775

Garfield, J., \& Ben-Zvi, D. (2007). How students learn statistics revisited: A current review of research on teaching and learning statistics. International Statistical Review, 75(3), 372-396. http://doi.org/10.1111/j.1751-5823.2007.00029.x

González Torres, H. J., \& Moreno Rossi, A. (2013). Apreciaciones sobre el uso y aplicación de la estadística en las ciencias de la salud. Duazary, 10(1), 62-66. Retrieved from http://0dialnet.unirioja.es.ubucat.ubu.es/descarga/articulo/4730381.pdf

Hernandez, J. A. E., Santos, G. R. dos, Silva, J. de O. da, Mendes, S. L. L., \& Ramos, V. da C. B. (2015). Evidências de validade da escala de ansiedade em estatística em alunos da psicologia. Psicologia: Ciência E Profissão, 35(3), 659-675. http://doi.org/10.1590/1982-3703000362014

Ing, E. (2016). Aids to statistics literacy for ophthalmologists. Canadian Journal of Ophthalmology/Journal Canadien D'ophtalmologie, 51(5), e142-e143. http://doi.org/10.1016/j.jcjo.2016.05.011

Leão, D. M. M. (1999). Paradigmas contemporâneos de educação: Escola tradicional e escola construtivista. Cadernos de Pesquisa, 107, 187-206. http://doi.org/10.1590/S010015741999000200008

León Bologna, E., \& Vaiman, M. (2013). Actitudes, experiencia previa y nivel de logro en Estadística en la carrera de Psicología. Probabilidad Condicionada: Revista de Didáctica de La Estadística, (2), 91-103. Retrieved from http://dialnet.unirioja.es/descarga/articulo/4770239.pdf

Lima, E. P. (2010). Epidemiologia e estatística: integrando ensino, pesquisa, serviço e comunidade. Revista Brasileira de Educação Médica, 34(2), 324-328. http://doi.org/10.1590/S010055022010000200019

Markert, R. J. (2013). Enhancing medical education by improving statistical methodology in journal articles. Teaching and Learning in Medicine, 25(2), 159-164. http://doi.org/10.1080/10401334.2013.770746

Nowacki, A. S. (2015). Teaching statistics from the operating table: Minimally invasive and maximally educational. Journal of Statistics Education, 23(1). Retrieved from www.amstat.org/publications/jse/v23n1/nowacki.pdf

Oliver, A., Sancho, P., Galiana, L., \& Cebrià i Sancho, M. Á. (2014). Nueva evidencia sobre la Statistical Anxiety Scale (SAS). Anales de Psicología, 30(1), 150-156. 
http://doi.org/10.6018/analesps.30.1.151341

Tavares, V. B. A. (2014). Massive Open Online Courses (MOOCS): Nova tendência educacional. Retrieved from http://bdm.unb.br/bitstream/10483/8387/1/2014_VivianeBrunellyTavares.pdf

Tempelaar, D. T., Gijselaers, W. H., \& Loeff, S. S. (2006). Puzzles in statistical reasoning. Journal of Statistics Education, 14(1).

Tishkovskaya, S., \& Lancaster, G. (2012). Statistical education in the 21st century: a review of challenges, teaching innovations and strategies for reform. Journal of Statistics Education, $20(2), 1-56$.

Torres, H. J., \& Moreno Rossi, A. (2013). Apreciaciones sobre el uso y aplicación de la estadística en las ciencias de la salud. Duazary, 10(1), 62-66. Retrieved from http://0dialnet.unirioja.es.ubucat.ubu.es/descarga/articulo/4730381.pdf

Turik, C., Viali, L., \& Moraes, J. F. D. de. (2012). Análise de atitudes de alunos universitários em relação à estatística por meio da teoria de resposta ao item. Ciência \& Educação (Bauru), 18(1), 231-243. http://doi.org/10.1590/S1516-73132012000100014

Vigil-Colet, A., Lorenzo-Seva, U., \& Condon, L. (2008). Development and validation of the statistics anxiety scale. Psicothema, 20(1), 174-180. http://doi.org/10.1177/1073191111421303

Zeidner, M. (1990). Does test anxiety bias scholastic aptitude test performance by gender and sociocultural group? Journal of Personality Assessment, 55(1-2), 145-160. http://doi.org/10.1080/00223891.1990.9674054

Zieffler, A., Garfield, J., Alt, S., Dupuis, D., Holleque, K., \& Chang, B. (2008). What does research suggest about the teaching and learning of introductory statistics at the college level? A review of the literature. Journal of Statistics Education, 16(2). Retrieved from www.amstat.org/publications/jse/v16n2/zieffler.html 